\title{
Assessment of Genetic Variability, Heritability and Genetic Advance for Morpho-physiological Traits in Early Maturing Genotypes of Indian Mustard
}

\author{
Ajay Pal Yadav ${ }^{*}$, Bhagirath Ram², Bhupendra Singh Yadav ${ }^{1}$ \\ and Hariom Kumar Sharma ${ }^{2}$
}

${ }^{1}$ Genetics and Plant Breeding) MJRP University Jaipur Rajasthan, India

${ }^{2}$ Genetics \& Plant Breeding, ICAR-Directorate of Rapeseed-Mustard Research, Bharatpur, Rajasthan, India

*Corresponding author

\section{A B S T R A C T}

Ke y w o r d s Indian mustard, Brassica juncea Morphophysiological Traits Article Info

Accepted: 15 December 2020 Available Online: 10 January 2021
Thirty advance breeding lines of Indian mustard [Brassica juncea (L.) Czern. and Coss.] genotypes including three check were evaluated in Complete Randomized Block Design (CRBD) with three replications during rabi 2019-20. The data were subjected to obtain estimate of genetic analysis of variance, heritability, genetic advance in relation to all fifteen morpho-physiological characters. The analysis of variance showed significant difference among genotype for all the characters. High estimate of heritability coupled genetic advance as percentage of mean was observed for 1000 -seed weight, siliquae per plant and seed yield per plant. High genotypic and phenotypic coefficient of variation are studied for MSI, siliquae per plant, seed yield per plant and WRCL.

\section{Introduction}

Rapeseed- mustard constitutes an important group of oilseed Brassica crops, and of these, Indian mustard [Brassica juncea (L.) Czern and Coss] is an important edible oil yielding crop accounting for about $80 \%$ of the cultivated area in North- Western parts of India (Singh et al., 2014). Amongst all the states in India, Rajasthan is an important producer of Indian mustard. Indian mustard is very sensitive to heat stress at early seedling stage. Although, early sowing has many advantages, the early sown-crop encounters high temperature stress, which results in a significant yield loss. High temperature stress is the most important abiotic stress affecting plant productivity around the world (Hall, 1992).).

Rapeseed mustard has the ability to grow under varied agro-climatic conditions relatively under low temperature as well as in the extremes of temperature regions (Downy 1983, Hanelts 2001). Indian mustard is an important edible oil yielding crop accounting 
for about $80 \%$ of the cultivated area in NorthWestern parts of India (Ram et al., 2014). Amongst all the states of India, Rajasthan is an important producer of Indian mustard. It is very sensitive to heat stress at early seedling stage. Although, early sowing has many advantages, the early sown-crop encounters high temperature stress, which results in a significant yield loss. Indian mustard to have greater tolerance to heat and water stress than the canola quality Indian mustard.

The cultivation of Indian mustard is largely carried out under the rainfed farming systems where sowing commences after south-west monsoon rains (Venkateswarlu and Prasad 2012). Early rains may cause the farmers to sow the crop early in the season to take advantage of the conserved moisture in the soil. But high temperature prevailing at the time of sowing reduces seed germination and causes seedling mortality, resulting in poor crop stand and reduced seed yield (Azharudheen et al., 2013).

Wide variations in diurnal soil temperatures ranging from $28{ }^{\circ} \mathrm{C}$ to $56{ }^{\circ} \mathrm{C}$ at the surface and from $33{ }^{\circ} \mathrm{C}$ to $37{ }^{\circ} \mathrm{C}$ at $300 \mathrm{~mm}$ depth were observed in Rajasthan (Gupta 1986). The average surface soil temperature may reach as high as $45^{\circ} \mathrm{C}$ during second fortnight of September and first fortnight of October In Rajasthan. This may lead to situation where the crop needs to be re-sown before a final successful crop is established. This causes a lot of economic loss to the farmers (Salisbury and Gurung 2011). More frequent weather aberrations and high temperature events are expected due to climate change scenario resulting in greater impact of heat on mustard production. Efforts to strengthen resilience are required by utilizing diverse heat tolerant genotypes in brassica crop improvement programmes. This will help to stabilize the productivity and to meet the growing demands of edible oil of the country.
Therefore, this study was designed to assess the genetic variability for seedling heat tolerance in the Indian mustard genotypes and to characterize the selected heat tolerant and susceptible genotypes. Thermotolerant genotypes identified in the study would have important bearing on brassica breeding programmes aimed at improving tolerance to heat stress at seedling stage.

\section{Materials and Methods}

The materials for the present investigation consisted of 30 genotypes of Indian mustard procured from the Directorate of RapeseedMustard Research (DRMR), Bharatpur. These genotypes were evaluated in complete randomized block design with 3 replications under heat stress conditions. Each genotype was grown in a plot of three rows, each row consisting with 5-meter length and plant to plant distance were maintained at $15 \mathrm{~cm}$ by thinning after 15-20 days of sowing.

Five competitive plants were randomly selected at the time of maturity (except the days to 50 per cent flowering and days to maturity which were recorded on plot basis) from each plot to record the following observations, i.e. plant height $(\mathrm{cm})$, primary branches per plant, secondary branches per plant, main shoot length $(\mathrm{cm})$, siliquae per plant, siliqua length $(\mathrm{cm})$, seeds per siliqua, seed yield per plant, 1000-seed weight (g), days to $50 \%$ flowering, days to maturity, relative water content $(\%)$, membrane stability index (\%), excised leaf water loss $(\%)$, water retention capacity of leaves $(\%)$.

\section{Determination of growth and physiological parameters}

\section{Membrane Stability Index (\%)}

Membrane stability index (MSI) was determined following the method of 
Premachandra et al., (1990) as modified by Sairam (1994). Leaf stripes (0.2 g) of uniform size were placed in test tubes containing 10 $\mathrm{ml}$ of double distilled water in two sets. Test tubes in one set were kept at $40{ }^{\circ} \mathrm{C}$ in a water bath for $30 \mathrm{~min}$ and electrical conductivity of the water containing the sample was measured $\left(\mathrm{C}_{1}\right)$ using a conductivity bridge.

Test tubes in the other set were incubated at $100{ }^{\circ} \mathrm{C}$ in boiling water in water bath for 15 min and electrical conductivity was measured as above $\left(\mathrm{C}_{2}\right)$. The MSI was calculated using the following formula:

$\mathrm{MSI}=\left[1-\mathrm{C}_{1} / \mathrm{C}_{2}\right] \times 100$

\section{Excised- Leaf Water Loss (\%)}

For determining excised- leaf water loss (ELWL), the leaves were weighed at three stages viz. immediately after sampling (fresh weight); after drying in an incubator at $28{ }^{\circ} \mathrm{C}$ and $50 \%$ R.H. for $6 \mathrm{~h}$; and after oven drying for $24 \mathrm{~h}$ at $70^{\circ} \mathrm{C}$ as suggested by Clarke, (1987). The ELWL was calculated using the following formula:

ELWL $=[$ Fresh weight - Weight after 6 h) $/$ (Fresh weight- Dry weight $] \times 100$

\section{Relative Water Content (\%)}

The samples for relative water content (RWC) were also weighed immediately to obtain fresh weight (FW); $2 \mathrm{~cm}$ leaf sections were floated in distilled water for $4 \mathrm{~h}$, blot-dried and weighed to obtain turgid weight (TW);

The $2.0 \mathrm{~cm}$ leaf sections were oven dried at $60{ }^{\circ} \mathrm{C}$ for $24 \mathrm{~h}$ and weighed to obtain dry weight (DW). The RWC was calculated using the formula of Barrs (1968):

$\mathrm{RWC}(\%)=[\mathrm{FW}-\mathrm{DW}) /(\mathrm{TW}-\mathrm{DW}] \times 100$

\section{Water Retention Capacity of leaves (\%)}

The water retention capacity of leaves (WRCL) was estimated by the method proposed by Ashraf and Ahmad (1998).

$\mathrm{WRCL}=\mathrm{Wt}$. of excised leaf each hours $/ \mathrm{Wt}$. of turgid excised leaf X 100

\section{Statistical analysis}

The data so obtained were subjected further to analysis of variance and the test of significant was performed according to Singh and Choudhary (1985) and critical difference (CD) calculated at 5\% probability level. The estimation of phenotypic coefficient of variation (PCV) and genotypic coefficient of variation $(\mathrm{GCV})$ was calculated as per the formula given by Johnson et al., (1955) and Burton (1952).

The heritability in broad sense $\left(\mathrm{h}^{2}\right.$ bs $)$ was estimated as the ratio of genotypic variance to the total variance. It was calculated by the formula given by Johnson et al., (1955). The expected genetic advance (GA) for each character was estimated by the formula as suggested by Johnson et al., (1955).

\section{Results and Discussion}

The analysis of variance for fifteen characters in thirty genotypes of Indian mustard is presented in Table 1. The critical perusal of table revealed that the highly significant genotypic traits difference were observed for plant height $(\mathrm{cm})$, primary branches per plant, secondary branches per plant, main shoot length $(\mathrm{cm})$, siliquae per plant, siliqua length $(\mathrm{cm})$, seeds per siliqua, seed yield per plant, 1000 -seed weight $(\mathrm{g})$, days to $50 \%$ flowering, days to maturity, relative water content $(\%)$, membrane stability index $(\%)$, excised leaf water loss $(\%)$, water retention capacity of leaves $(\%)$. 
Table.1 Analysis of variance (ANOVA) for morpho-physiological characters of Indian mustard during rabi 2019-20

\begin{tabular}{|c|c|c|c|c|c|c|c|c|c|c|c|c|c|c|c|c|c|}
\hline \multirow[b]{2}{*}{$\begin{array}{l}\text { Source of } \\
\text { variation }\end{array}$} & \multirow[b]{2}{*}{ d.f. } & \multicolumn{16}{|c|}{ Mean Square } \\
\hline & & $\begin{array}{c}\text { Days to } \\
50 \% \\
\text { flowerin } \\
\mathrm{g}\end{array}$ & $\begin{array}{c}\text { Plant } \\
\text { Height } \\
\text { (cm) }\end{array}$ & $\begin{array}{c}\text { Primary } \\
\text { Branch }\end{array}$ & $\begin{array}{c}\text { Seconda } \\
\text { ry } \\
\text { Branch }\end{array}$ & $\begin{array}{c}\text { Main } \\
\text { Shoot } \\
\text { Length } \\
\text { (cm) }\end{array}$ & $\begin{array}{c}\text { Siliquae/ } \\
\text { plant }\end{array}$ & $\begin{array}{c}\text { Siliqu } \\
\text { a } \\
\text { Lengt } \\
\text { h } \\
(\mathrm{cm})\end{array}$ & $\begin{array}{c}\text { Seeds } \\
\text { per } \\
\text { Siliqu } \\
\text { a }(\mathbf{g})\end{array}$ & $\begin{array}{l}\text { Days } \\
\text { to } \\
\text { maturi } \\
\text { ty }\end{array}$ & $\begin{array}{c}\text { Seed } \\
\text { yield } \\
\text { per } \\
\text { plant } \\
\text { (g) }\end{array}$ & $\begin{array}{c}1000 \\
\text { seed } \\
\text { weigh } \\
t(g)\end{array}$ & $\begin{array}{c}\text { Days to } \\
\text { maturit } \\
y\end{array}$ & $\begin{array}{c}\text { RWC } \\
(\%)\end{array}$ & $\begin{array}{l}\text { MSI } \\
(\%)\end{array}$ & $\begin{array}{l}\text { ELW } \\
L(\%)\end{array}$ & $\begin{array}{c}\text { WRCL } \\
(\%)\end{array}$ \\
\hline Replication & 2 & 9.54 & 17.70 & 1.23 & 0.69 & 1.02 & 917.48 & 0.58 & 0.10 & 147.40 & 1.32 & 0.24 & 147.40 & 74.62 & 886.07 & 115.62 & 202.96 \\
\hline Treatment & 29 & $23.06 * *$ & $\begin{array}{c}124.42 \\
* *\end{array}$ & $0.63 * *$ & $10.10 * *$ & $\begin{array}{c}25.55 \\
* *\end{array}$ & $\begin{array}{c}7319.84 \\
* *\end{array}$ & $\begin{array}{c}0.42 \\
* *\end{array}$ & $\begin{array}{c}2.09 \\
* *\end{array}$ & $\begin{array}{c}316.77 \\
* *\end{array}$ & $50.92 * *$ & $.88 * *$ & $\begin{array}{l}316.77 \\
* *\end{array}$ & $\begin{array}{l}44.21 \\
*\end{array}$ & $\begin{array}{l}217.27 \\
* *\end{array}$ & $\begin{array}{l}8.64 \\
* *\end{array}$ & $\begin{array}{l}\text { 83.69 } \\
* *\end{array}$ \\
\hline
\end{tabular}

Table.2 Genetic Variability of Morpho-physiological characters of Indian Mustard

\begin{tabular}{|c|c|c|c|c|c|}
\hline Characters & Heritability (\%) & GCV & PCV & Genetic Advance & $\begin{array}{c}\text { Genetic Advance } \\
\text { as per percentage } \\
\text { of means }\end{array}$ \\
\hline Days to $50 \%$ flowering & 35.678 & 4.805 & 8.044 & 2.712 & 5.912 \\
\hline Plant height (cm) & 57.533 & 3.563 & 4.698 & 9.015 & 5.568 \\
\hline Primary branch & 8.752 & 3.809 & 12.875 & 0.128 & 2.321 \\
\hline Secondary branch & 39.637 & 12.183 & 19.351 & 1.938 & 15.8 \\
\hline Main shoot length $(\mathrm{cm})$ & 28.74 & 3.606 & 6.726 & 2.484 & 3.982 \\
\hline Siliquae per plant & 56.698 & 16.142 & 21.437 & 68.406 & 25.038 \\
\hline Siliqua length $(\mathrm{cm})$ & 61.042 & 7.87 & 10.073 & 0.523 & 12.667 \\
\hline Seeds per siliqua & 46.774 & 5.322 & 7.782 & 0.999 & 7.498 \\
\hline Days to maturity & 49.434 & 5.26 & 7.481 & 10.425 & 7.618 \\
\hline Seed yield per plant (g) & 59.002 & 15.296 & 19.913 & 5.874 & 24.203 \\
\hline 1000 seed Weight (g) & 61.405 & 10.506 & 13.407 & 0.782 & 16.959 \\
\hline RWC (\%) & 24.364 & 3.277 & 6.639 & 2.737 & 3.332 \\
\hline MSI (\%) & 45.756 & 17.449 & 25.796 & 10.04 & 24.315 \\
\hline ELWL (\%) & 21.595 & 6.073 & 13.068 & 1.093 & 5.814 \\
\hline WRC (\%) & 46.806 & 13.315 & 19.462 & 6.34 & 18.765 \\
\hline
\end{tabular}


Genetic variability parameters for morpho- physiological traits

\section{Coefficient of variation}

The genotypic and phenotypic coefficient of variation in fifteen characters in thirty genotypes of Indian mustard are furnished in Table 2. It was revealed that the GCV for MSI (17.44), siliquae per plant (16.14), seed yield per plant (15.29), WRCL (13.31), secondary branches per plant (12.18), were high. However, moderate GCV were observed for 1000-seed weight (10.50), siliqua length (7.87), ELWL (6.07), seeds per siliqua (5.32) and days to maturity (5.26).

The highest phenotypic coefficient of variation $(\mathrm{PCV})$ was observed for MSI (25.79), siliquae per plant (21.43), seed yield per plant (19.91), WRCL (19.46) and secondary branches per plant (19.35). Moderate PCV were recorded for 1000-seed weight (13.40), ELWL (13.06), primary branches per plant (12.87), siliqua length (10.07) and days to 50\% flowering (8.04).

\section{Heritability and genetic advance}

The estimates of heritability in broad sense and expected genetic advance for fifteen character in thirty genotypes of Indian mustard are present in table 2 . The estimate of heritability in broad sense were recorded high for 1000-seed weight (61.40), siliqua length (61.04), seed yield per plant (59.00), plant height (57.53) and siliquae per plant (56.69). However moderate heritability were observed for days to maturity (49.43), WRCL (46.80), siliquae per plant (46.77), MSI (45.75), secondary branches per plant (39.63) and days to $50 \%$ flowering (35.67)). High heritability coupled with genetic advance as percentage of mean was exhibited by excised leaf water loss similar observation were reported by Ram et al., (2017) and Tirpathi et al., (2019).
Thousand seed weight expressed high heritability accompanied with genetic advance as percentage of mean which is in accordance with genetic advance as percentage of mean. These same results have been reported by Ram et al., (2015), Roy et al., (2015), Ram et al., (2017), Kumar et al., (2018) and Tirpathi et al., (2019).

The highest value of expected genetic advance as percentage of mean for siliquae per plant (25.03), MSI (24.31), seed yield per plant (24.20), WRCL (18.76) and secondary branches per plant (15.8). However, medium value of expected genetic advance as percentage of mean was obtained for 1000seed weight (16.95), siliqua length (12.66), days to maturity (7.61), seeds per siliqua (7.49) and days to $50 \%$ flowering (5.91).

In conclusion, we report that Membrane stability index (17.44) showed maximum genotypic coefficient of variation followed by siliquae per plant (16.14), seed yield per plant (15.29), WRCL (13.31), secondary branches per plant (12.18). Heritability estimates (broad sense) was maximum for 1000-seed weight (61.40), siliqua length (61.04), seed yield per plant (59.00), plant height (57.53) and siliquae per plant (56.69).Expected genetic advance as percent mean was maximum for siliquae per plant (25.03), MSI (24.31), seed yield per plant (24.20), WRCL (18.76) and secondary branches per plant (15.8).

\section{References}

Ashraf M., Ahmad M.M. (1998). Relationship between water retention capability and osmotic adjustment in sorghum (sorghum bicolor) grown under drought stress. Arid Soil Res.Rehab., 12: 255262.

Azharudheen T.P.M., Yadava D.K., Singh N., Vasudev S., Prabhu K.V. (2013). 
Screening Indian mustard (Brassica juncea L. Czern \& Coss.) germplasm for seedling thermo-tolerance using a new screening protocol. Afr. J. Agric. Res., 8: 4755-4760.

Barrs H.D. (1968). Determination of water deficits in plant tissues. In: T.T. Kozolvski, eds., Water deficits and plant growth, Vol 1, Academic Press, New Delhi., pp. 235-368.

Burton G.W. (1952). Quantitative inheritance in grasses. Proceeding of $6^{\text {th }}$ international Grassland Congress., 1: 227-283.

Clarke J.M. (1987). Use of physiological and morphological traits in breeding programmes to improve drought resistance of cereals. In: Srivastava J.P., Porcedo E., Acevedo E., Varma S., eds., Drought tolerance in winter cereals, John Wiley \& Sons, New York., pp. 171-190.

Downey R.K. (1983). The origin and description of Brassica oilseed crops. In: Kramer., Sauer. and Pigden. (eds) High and Low erucic acid rapeseed oils: Production, Usage, Chemistry and Toxicological Evaluation., Academics Press, New York, 1-20.

Gupta J.P. (1986). Moisture and thermal regimes of the desert soils of Rajasthan, India, and their management for higher plant production. Hydrological Sciences Journal., 31: 347-359.

Hall AE. (1992). Breeding for heat tolerance. Plant Breed Rev 10: 129-168.

Hanelt P. (2001). Brassicaceae. In: Hanlet P., Institute of Plant Genetics, Crop Plant Research, (eds) Mansfield Encyclopedia of agriculture and horticulture crops., vol 4. Springer, Vienna., pp 1435-1481.

Johnson H.W., Robinson H.F. and Comstock R.E. (1955). Estimates of genetic and environmental variability in soyabean. Agronomy Journal., 47: 314-318.

Johnson H.W., Robinson H.F. and Comstock
R.E. (1955). Genotypic and phenotypic correlation in soybean and their implication in selection. Agron., 47: 477-483.

Kumar Anil., Upadhyay P.K., Ram Bhagirath. and Tomar Rajni. (2018). Genetic variability and character association for morphological and seed yield related traits in Indian mustard (Brassica juncea L. Czern \& Coss) germplasm under heat stress conditions. Indian Res. J. Genet. \& Biotech., 10(2): 288-295.

Premachandra G. S., Saneoka H. and Ogata S. (1990). Cell membrane stability an indicator of drought tolerance as affected by applied nitrogen in soyabean. J. Agric. Sci. (Camb)., 115: 63-66.

Ram Bhagirath., Meena H.S., Singh V.V., Singh B.K., Nanjundan J., Kumar Arun., Singh S.P., Bhogal N.S. and Singh Dhiraj. (2014). High temperature stress tolerance in Indian mustard (Brassica juncea) germplasm as evaluated by membrane stability index and excisedleaf water loss techniques. Journal of Oilseed Brassica., 5(2): 149-157.

Ram Bhagirath., Singh V.V., Meena H.S., Kumar A., Singh B.K. and Singh Dhiraj. (2017). Genetic analysis of heat stress tolerance in Indian mustard (Brassica juncea L.). Indian Journal of Agricultural Sciences., 87(1): 79-82.

Ram Bhagirath., Singh V.V., Singh B.K., Priyamedha., Kumar Arun., Singh Dhiraj. (2015). Comparative tolerance and sensitive response of Indian mustard (Brassica juncea L. Czern. and Coss.) genotypes to high temperature stress. SABRAO Journal of Breeding and Genetics., 47(3) 315-325.

Roy S.K., Kale V.A. and Nagnathwar V.A. (2015). Assessment of genetic variability of rapeseed-mustard germplasm under Trai region of West Bengal. Electronic J. of Plant Breeding., 
32: 593-594.

Sairam R.K. (1994). Effect of moisture stress on physiological activities of two contrasting wheat genotypes. Ind. J. Exp. Biol., 32: 593-594.

Salisbury P., Gurung A. (2011). Final report on oilseed brassica improvement in China, India and Australia. In: Australian Centre for International Agricultural Research, Canberra, Australia., pp. 9-10.

Singh R.K. and Choudhary B.D. (1985). Variance and covariance analysis. Biometrical Method in Quantitative Genetic Analysis. Kalyani Publisher, Ludhiana pp. 39-68.

Singh V.V., Ram Bhagirath., Singh M., Meena M.L., Chauhan J.S. (2014).
Generation mean analysis for water stress tolerance parameters in Indian mustard [Brassica juncea (L.) Czern \& Coss] Crosses. SABRAO J. Breed. Genet., 46: 76-80.

Tripathi Neeta., Kumar K., Tiwari Rita. and Verma O.P. (2019). Assessing genetic variability in Indian mustard (Brassica juncea L. Czern. and Coss.) for seed yielding and it's contributing attributes under normal and saline/alkaline condition. J. of Pharmacognosy and Phytochemistry., 8(2): 1322-1324.

Venkateswarlu B., Prasad J.V.N.S. (2012). Carrying capacity of Indian agriculture: issues related to rainfed agriculture. Current Science., 102: 882-888.

\section{How to cite this article:}

Ajay Pal Yadav, Bhagirath Ram, Bhupendra Singh Yadav and Hariom Kumar Sharma. 2021. Assessment of Genetic Variability, Heritability and Genetic Advance for Morpho-physiological Traits in Early Maturing Genotypes of Indian Mustard. Int.J.Curr.Microbiol.App.Sci. 10(01): 2562-2568. doi: https://doi.org/10.20546/ijcmas.2021.1001.297 